\title{
THE USE OF THE SYSTEM OF HEURISTIC METHODS IN THE PROCESS OF ARTISTIC DESIGN OF CLOTHING
}

\section{ВИКОРИСТАННЯ СИСТЕМИ ЕВРИСТИЧНИХ МЕТОДІВ У ПРОЦЕСІ ХУДОЖНЬОГО ПРОЄКТУВАННЯ ОДЯГУ}

\author{
Nataliia ORLOVA, \\ Assistant \\ Наталія ОРЛОВА, \\ асистент \\ https://orcid.org/0000-0002-5071-869X \\ orlovanatstan@gmail.com \\ Poltava V.G. Korolenko National \\ Полтавський національний \\ Pedagogical University \\ педагогічний університет імені \\ 2 Ostrogradsky St., \\ В.Г. Короленка \\ Poltava, 36000 \\ вул. Остроградського, 2 \\ м. Полтава, 36000
}

Original manuscript received: October 12, 2019

Revised manuscript accepted: December 16, 2019

\begin{abstract}
The process of designing new design objects, especially in the fashion industry, is extremely complex and multi-elemental, as it involves not only the mind, knowledge and skills of the artist, but also his inner feelings and observations. This process consists of a number of defined stages - from the idea-concept, through the formulation of tasks, the formation of the concept and the choice combined in a different sequence of techniques, means and methods of design to the implementation of the idea in life. The question of choice and application of one particular design method, or their complex, in each case under consideration, stands in front of the developer and requires him as an awareness of the design objectives and understanding of the possibilities of the used methods. To solve the creative problem of using traditional design methods does not give new interesting solutions. Therefore, it is important to activate the creative search, which is aimed at developing the students' creative thinking and intensifying the design process. It may be fruitful to study and put into practice, together with traditional empirical techniques, non-traditional methods, so-called technological techniques of creativity. These techniques can be successfully designed for the educational process in general and higher education.

There are many different heuristic methods that can awaken students' initiative, reveal their individual creative abilities, develop the logic of thinking in a professional direction, regulate and intensify the process of creative search. Along with this, there is a need to develop methods of teaching the artistic design of students' clothing and adapt to the modern curricula of higher education institutions, to expand the experience of learning new pedagogical technologies. The task of scientists is to bring these methods closer to the needs of pedagogical practice.

Key words: heuristic methods, heuristic training, methods of designing clothes, artistic designing of clothes, creative abilities.
\end{abstract}


Серія: Педагогічні науки. - Вип.3. - Бердянськ : БДПУ, 2019. - 453 с.

На сучасному етапі розвитку нашої держави зростає потреба у вдосконаленні процесу підготовки нового покоління конкурентоспроможних педагогічних працівників, яка передбачає вивчення й урахування індивідуальних здібностей кожного студента в інтелектуальній, емоційно-вольовій сферах, у різних видах навчальновиховної діяльності. Навчання майбутніх вчителів трудового навчання та технологій має бути орієнтованим на розвиток евристичного мислення й здібностей учнів задля успішного здійснення ними своєї творчої самореалізації. Освітній процес вищої школи вимагає опрацювання й упровадження евристичного навчання як ефективного засобу організації творчої діяльності студентів, оскільки проблема вдосконалення підготовки майбутніх учителів трудового навчання та технологій до формування евристичних умінь учнів $€$ надзвичайно актуальною на сьогодні. Мета дослідження: обґрунтувати перспективи застосування евристичних методів проєктування для успішного розвитку творчих здібностей студентів на заняттях із художнього проєктування одягу. Реалізація поставленої мети передбачає вирішення таких завдань: визначити науково-теоретичні передумови формування творчих здібностей особистості в процесі художньо-конструкторської діяльності по розробці конструкції нової моделі одягу; виявити можливості використання нетривіальних шляхів рішення творчих завдань проєктування, подолання психологічної інерції через застосування евристичних методів; теоретично обґрунтувати й визначити структуру художньо-конструкторської діяльності в умовах її організації як одного із засобів розвитку творчого потенціалу особистості.

До проблеми використання евристичних методів навчання, виховання активної, самостійної, творчої особистості у своїх дослідженнях зверталися В. Андреєв [1], П. Каптєрєв [5], М. Лазарєв [10], Т. Лисянська [11], В. Лозова [12], А. Хуторськой [15] тощо. Вивчення психологопедагогічної літератури дозволило виявити протиріччя між динамікою розвитку суспільства, що висуває нові вимоги до навчання, та його якістю в закладах вищої освіти; необхідністю володіння сучасним викладачем методикою використання евристичних методів як засобом підвищення ефективності освіти, створенням умов для творчої самореалізації студентів та відсутністю науково-методичного забезпечення цього процесу із застосуванням евристичних методів навчання.

Уперше вчення про евристичні методи розроблено і введено в практику Сократом. Поняття “евристика”, “евристичний” обов'язково відзначають такі прояви матеріальної та практичної діяльності людини, які мають елементи відкриття, нових знахідок, оригінальних рішень. Евристика орієнтована на створення особистістю суб'єктивного або об'єктивного нового значущого продукту. “Евристичні методи забезпечують виявлення, обробку і впорядкування системи закономірностей, механізмів і методологічних засобів конструювання нового завдання та цілеспрямованих способів діяльності на основі узагальнення колишнього досвіду та випереджального відображення 
моделей майбутнього з метою вирішення поставленої задачі найбільш ефрективно" [4].

Евристичне навчання - оригінальна науково-педагогічна концепція, яка пропонує студентам самостійно "відкривати знання", порівнюючи їх із культурно-історичними аналогами, вибудовуючи при цьому індивідуальну траєкторію власної освіти. Основна ідея евристичного навчання розкриття творчого потенціалу кожної особистості, зумовлене цим ставлення її пізнавально-творчої (пошукової, дослідницької, проєктної, художньої, конструкторської) діяльності на перше місце в усій системі навчання. Ця інноваційна освітня технологія передбачає, насамперед, уміння студентів виявляти проблему, визначати мету, завдання й безпосередньо, знаходити свої варіанти ії розв'язання [8].

А. Хуторськой вважає, що евристика - це спрямованість діяльності людини, орієнтована на створення нею суб'єктивно або об'єктивно нового і значимого продукту. Досліджуючи дидактичну евристику, вчений стверджує, що мета евристичного навчання полягає в тому, щоб надати студентам можливість творити знання, створювати освітню продукцію 3 усіма навчальними предметами; навчити їх самостійно вирішувати проблеми, що виникають при цьому [15].

В. Лозова визначає, що евристичне навчання передбачає достатнє володіння такими механізмами, методами й прийомами творчої діяльності такими, як "аналіз через синтез", “мозковий штурм", евристичні запитання, методи розвитку емпіричних знань до рівня теоретичних асоціацій, порівняння, узагальнення, абстрагування, об'єктивна діагностика й оцінювання власної чи чужої роботи тощо [12].

В. Андреєв розглядає евристичні методи навчально-творчої діяльності як систему евристичних правил діяльності педагога (методи викладання) та діяльності студента (методи навчання), що розроблені 3 урахуванням закономірностей та принципів педагогічного управління та самоуправління особистості для розвитку інтуїтивних процедур діяльності студентів щодо вирішення творчих завдань [1].

Особливістю методу в художньому проєктуванні одягу $\epsilon$ спрямованість проектних дій одночасно і на прагматичний, і на художній результати, причому ієрархія відповідних установок і шляхів їх досягнення може змінюватися в процесі роботи. Це означає, що "метод і методика дизайнера повинні містити елементи, які поєднують у собі можливості інженерно-технічної і художньої творчості, що зумовлює специфіку його підготовки та технології професійної роботи" [9].

Сучасні евристичні методи інтенсифікації процесу художнього проєктування одягу класифрікують так: методи проєктування (аналогії, асоціації, неології, евристичне комбінування, антропотехніка, передових технологій тощо); методи, які використовуються при осмисленні поставленого завдання (навідне завдання-аналог, зміна формулювання завдання, перелік недоліків тощо); методи, що дають нові парадоксальні рішення (інверсія, емпатія, “мозкова атака", "нарада піратів", дельфійський, карикатури тощо); методи математичного аналізу 
(семикратний пошук, побудова матриць і мереж взаємодії, генерування ідей на основі побудови діаграм тощо); методи, в яких використовуються професійні ігри [2].

Метод контрольних запитань $€$ одним 3 методів психологічної активізації творчого процесу. Його мета - за допомогою додаткових запитань підвести студентів до розв'язання задачі. Суть методу переліку недоліків полягає в складанні повного, розгорнутого списку недоліків виробу. Перелік недоліків відразу ж дає чітку картину, які з них, у першу чергу, потрібно усунути. Основна мета методу пошуку “ідеальної речі" полягає в такій постановці завдання, при якій особлива увага приділяється функціональному призначенню об'єкта.

Досить часто для отримання нових результатів розробники одягу застосовують метод аналогій, що базується на використанні аналогічних рішень. Розпізнають такі джерела аналогій: прямі, суб'єктивні, символічні, фантастичні. Схожим до методу аналогії $\epsilon$ метод неонології [3], заснований на використанні чужих ідей, новацій, передового вітчизняного та зарубіжного проєктування.

Асоціації - метод формування ідеї. Дизайнера одягу завжди цікавить як форма взагалі, так і сполучення об'ємів, поєднання різноманітних побудов. Він з реальної дійсності може взяти майже все, що якимсь чином може трансформуватися, перетворитися в одяг: мотив, фрагмент чогось або джерело в цілому. Творчими джерелами при проєктуванні одягу можуть бути будь-які явища природи, події в суспільстві, предмети дійсності, які нас оточують. Асоціації можуть бути різноманітні: предметні, абстрактні, психологічні, ірреальні.

Метод деконструкції (вперше помічений на початку 80-х років минулого століття) - будь-яке свідоме порушення традиційних технологій: асиметричний крій, прорізи та дірки, елементи незавершеності (блузи, куртки з одним рукавом) та інше [7]. Інверсія - метод проєктування "від протилежного" або метод “перевороту". Він сприяє всебічному розвитку гнучкості мислення проєктувальника і дозволяє отримати абсолютно нові, інколи парадоксальні рішення. Можна нагадати деякі приклади застосування цього методу в дизайні одягу: одяг, зшитий швами назовні; сумки з безліччю зовнішніх кишень; двосторонні пальта, плащі, костюми, жилети, які можна носити на обидві сторони тощо [14].

Комбінаторний метод полягає в пошуку різних комбінацій на основі визначених фрорм та елементів у певному порядку шляхом перестановок, згрупувань, вставок, поєднань, переворотів, комбінування деталей [3, 6, 13]. Як різновид комбінаторного методу деякі дослідники виділяють методи трансформації та кінематизму. Антропотехніка - метод проєктування нових об'єктів, що враховує їх пристосовуваність до фізичних можливостей людини. Навіть в авангардних моделях необхідно враховувати пропорції людського тіла. Для активізації й розвитку творчого пошуку студентів досить широко можна використати надбання методу синектики, який значно стимулює розумові процеси, 
спрямованість яких, як правило, є достатньо несподіваною і випадковою. Синектика дає керівництво до генерації нових ідей [2].

Дельфійський метод - метод експертного прогнозування шляхом організації системи збору експертних оцінок, їх математично-статистичної обробки і послідовного коригування на основі результатів кожного циклу обробки. Метод карикатури або метод гіперболи - це доведення творчого задуму до гротескового, абсурдного вигляду. Він сприяє виникненню нових, неочікуваних вирішень, розвитку творчої уяви та допомагає дизайнерові визначити межі образної моделі (Д. Ван Ноттен, Дж. Гальяно) [7].

“Метод доладного розуму" - з'ясування думки інших використовується на заняттях із студентами і навіть у дизайнерських бюро, де колективно розробляють проблему. На основі висловлених зауважень визначається оптимальний варіант вирішення проєктної задачі. Семикратний пошук - метод, побудований на семи ключових питаннях: “Хто? Що? Де? Чим? Навіщо? Як? Коли?", які вживаються для виявлення проблем і формулювання творчого завдання [2].

Із перерахованих методів можна вибрати будь-який, що найбільше відповідає вирішенню конкретної задачі, або групу методів і використовувати їх при проєктуванні. Іноді викладачу доцільно розбити проєктне завдання на декілька більш простих та доступніших для вирішення. Методи евристичного навчання використовують у навчальновиховному процесі викладачі фракультету технологій та дизайну Полтавського національного педагогічного університету імені В. Г. Короленка. Евристичні методи проєктування одягу застосовують при вивченні таких дисциплін, як "Дизайн одягу" та "Дизайн-практикум 3 конструювання та моделювання одягу". Студенти часто користуються простими евристичними прийомами, що базуються на методах аналогії, асоціації, комбінування, інверсії та ін. Майбутні вчителі трудового навчання та технологій стикаються $з$ інтерпретацією творчого джерела і перетворюють його шляхом трансформацій у проєктне рішення.

Джерелом натхнення для цих методів може стати будь-що 3 оточення: національний одяг, інженерні рішення, твори мистецтва і т.п. Наприклад: студентки факультету технологій та дизайну трансформували колоритні писанкові мотиви в ескізи жіночих суконь та костюмів нової колекції “Полтавська писанка”. У кожній моделі прослідковується кольорова гама та символіка певної полтавської писанки. На Полтавщині яйця розфарбовують білими, жовтими та зеленими барвами з червоним, коричневим, чорним і зеленим розписом. Різноманіття орнаментів із солярних знаків та рослинних мотивів доповнюється зображеннями людей, тварин і птахів (“полтавські сороки” та “пави”).

При художньому проєктуванні одягу з використанням символів традиційного писанкарства та їх композиційного розміщення на виробі застосовують різноманітні декоративні техніки: печворк, аплікацію, розпис по тканині та інші. Дизайн одягу на основі писанкових мотивів створений за допомогою таких засобів: конструктивне перетворення писанки; декоративний підхід; трансформація символіки писанки в художній образ 
виробу. Використання найрізноманітніших евристичних методів дозволяє проявити майбутньому вчителю трудового навчання та технологій ініціативу, розкрити його індивідуальні творчі здібності, розвинути логіку мислення в професійному напрямі.

Висновки. Аналізуючи фахові та наукові джерела за обраною проблемою, можна зазначити, що на сьогодні існує значна кількість методів проєктування одягу, які допомагають розробнику втілити свій задум у життя. Але в процесі творчої діяльності дизайнер не завжди заздалегідь планує застосування вищезазначених та інших методів. Він орієнтується на поставлені цілі, завдання і пов'язані з цим головні методологічні підходи, адже процес творчості настільки складний, багатоплановий та інколи суперечливий, що визначити, які саме методи використовувалися в той чи інший момент, можна лише на основі дослідження результатів роботи. Творчий процес, у свою чергу, не може існувати без єдності мислення, почуттів, уяви та певного емоційного настрою.

Таким чином, під час навчання художнього проєктування одягу вбачається плідним вивчення і практичне впровадження разом 3 емпіричними прийомами евристичних методів інтенсифікації творчої фантазії. Вивчення цих методів спрямоване, насамперед, на формування творчої особистості вчителя, який має високу естетичну культуру в поєднанні з професійними вміннями та продуктивно використає їх у підготовці учнів до творчої діяльності.

\section{Література}

1. Андреев В.И. Педагогика творческого саморазвития: инновационный курс / В.И. Андреев. - Казань : Изд-во КГУ, 1998. - Кн. 2. - 320 с.

2. Гур'янова О. Активізація творчого мислення студентів за допомогою нових педагогічних технологій / О. Гур'янова - Режим доступу: http://dspace.kspu.kr.ua/jspui/bitstream/123456789/247/1/Активізація\%20творчого\%2 0мислення\%20студентів\%20за\%20допомогою\%20нових\%20педагогічних\%20техно логій\%20 120.pdf (дата звернення: 21.07.2019) - Назва з екрана

3. Гусейнов Г.М. Композиция костюма: учеб.пособие для студентов вузов / Г.М Гусейнов, В.В. Ермилова, Д.Ю. Ермилова и др. - М.: Академия, 2003. - 432 с.

4. Евристичні методи їх загальна характеристика - Режим доступу: http://uareferat.com/Евристичні_методи_їх_загальна_характеристика (звернення: 20.07.2019).

5. Каптерев П. Ф. Эвристическая форма обучения в народной школе // Антология педагогической мысли России второй половины XIX — начала XX в. М.: Педагогика, 1990. - С. 218-221.

6. Килошенко М.И. Психология моды: Учебное пособие для вузов / М.И. Килошенко. - 2-е издание, испр. - М.: Оникс, 2006. - 320 с.: ил.

7. Косяк І.В. Взаємодія механізму творчості та сучасних методів проектування в дизайні одягу / І.В. Косяк - Режим доступу: http://www.enpuir.npu.edu.ua/bitstream/ 123456789/7308/1/Kosiak.pdf (звернення: 25.07.2019).

8. Кривонос О.Б. Активізація пізнавально-творчої діяльності учнів в умовах евристичного навчання: [монографрія] / [за ред.. проф. Лазарєва М.О.] / О.Б. Кривонос. - Суми: Вид-во СумДПУ ім.. А.С. Макаренка, 2014. - С. 65-86.

9. Лагода О.М. Художньо-образні особливості костюма в дизайні одягу кінця XX початку XXI століття: : автореф. дис. на здобуття наук. ступеня канд. 
мистецтвознав. : 17.00.07 / Лагода Оксана Миколаївна; Харк. держ. акад. диз. і мист. - Харків, 2007. - 22 с.

10. Лазарєв М. О. Евристична діяльність - основа сучасного навчального процесу / М. О. Лазарев // Педагогічні науки: теорія, історія, інноваційні технології. - 2009. - № 1. - С. 92 - 104.

11. Лисянська Т. М. Мислення / Т. М. Лисянська // Загальна психологія. Київ : Либідь, 2005. - С. 139 - 174.

12. Лозова В. І. Цілісний підхід до формування пізнавальної активності школярів / В. І. Лозова. - Харків : Основа, 2002. - 111 с.

13. Рачинская Е.И. Моделирование и художественное оформление одежды / Е.И. Рачинская, В.И. Сидоренко. - Ростов н/Д.: Феникс, 2002. - 608 с.

14. Розвиток творчих здібностей учнів основної загальноосвітньої школи 3 конструювання та моделювання одягу на уроках трудового навчання - Режим доступу: http://otherreferats.allbest.ru/pedagogics/00320680 0.html (дата звернення: 21.07.2019).

15. Хуторской А. В. Дидактическая эвристика. Теория и технология креативного обучения / А. В. Хуторской. -Москва : Изд-во МГУ, 2003. - 416 с.

\section{References}

1. Andreev V.Y. (1998). Pedahohyka tvorcheskoho samorazvytyia: ynnovatsyonnyi kurs - Kn. 2. [Pedagogy of creative self-development: an innovative course]. Kazan: Yzd-vo KHU [in Russian].

2. Hurianova, O. Aktyvizatsiia tvorchoho myslennia studentiv za dopomohoiu novykh pedahohichnykh tekhnolohii. [Activation of students' creative thinking with the help of new pedagogical technologies]. - Rezhym dostupu: http://dspace.kspu.kr.ua/jspui/bitstream/123456789/247/1/Aktyvizatsiia\%20tvorchoho\% 20 myslennia\%20studentiv\%20za\%20dopomohoiu\%20novykh\%20pedahohichnykh\%20t ekhnolohii\%20_120.pdf (data zvernennia: 21.07.2019) [in Ukrainian].

3. Huseinov, H.M., Ermylova, V.V., Ermylova, D.lu. i dr. (2003). Kompozytsyia kostiuma: Uchebnoe posobye dlia studentov vuzov. [Costume Composition: A textbook for university students]. Moscow: Akademyia [in Russian].

4. Evrystychni metody yikh zahalna kharakterystyka. [Heuristic methods are their general characteristic]. - Rezhym dostupu: http://uareferat.com/Evrystychni metody yikh zahalna kharakterystyka (data zvernennia: 20.07.2019) [in Ukrainian].

5. Kapterev P. F. (1990). Evrystycheskaia forma obuchenyia v narodnoi shkole // Antolohyia pedahohycheskoi mysly Rossyy vtoroi polovyny XIX - nachala XX v. [An heuristic form of teaching in a public school // Anthology of pedagogical thought of Russia in the second half of XIX - beginning of XX century], (pp. 218-221). Moscow: Pedahohyka [in Russian].

6. Kyloshenko, M.Y. (2006). Psykholohyia mody: Uchebnoe posobye dlia vuzov - 2-e yzdanye, yspr. [Fashion Psychology: A textbook for Universities]. Moscow: Onyks [in Russian].

7. Kosiak, I.V. Vzaiemodiia mekhanizmu tvorchosti ta suchasnykh metodiv proektuvannia $v$ dyzaini odiahu. [The interaction of the mechanism of creativity and modern design methods in the design of clothing] - Rezhym dostupu: http://www.enpuir.npu.edu.ua/bitstream/ 123456789/7308/1/Kosiak.pdf (data zvernennia: 25.07.2019) - Nazva z ekrana [in Ukrainian].

8. Kryvonos O.B. (2014). Aktyvizatsiia piznavalno-tvorchoi diialnosti uchniv $v$ umovakh evrystychnoho navchannia: [monohrafiia] / [za red. prof. Lazarieva M.O.]. [Activation of cognitive and creative activity of students in the context of heuristic learning: [monograph]], (pp. 65-86.). Sumy: Vyd-vo SumDPU im. A.S. Makarenka. [in Ukrainian]. 
9. Lahoda, O.M. (2007). Khudozhno-obrazni osoblyvosti kostiuma v dyzaini odiahu kintsia XX - pochatku XXI stolittia: avtoref. dys. na zdobuttia nauk. stupenia kand. mystetstvoznav. [Artistic and figurative features of the costume in the design of clothing of the late XX - early XXI century]. Kharkiv.: Ranok. [in Ukrainian].

10. Lazariev M. O. (2009). Evrystychna diialnist - osnova suchasnoho navchalnoho protsesu // Pedahohichni nauky: teoriia, istoriia, innovatsiini tekhnolohii - № 1. [Heuristic activity is the basis of the modern educational process], (pp. 92 - 104) [in Ukrainian].

11. Lysianska T. M. (2005) Myslennia // Zahalna psykholohiia. [Thinking // General psychology], (pp. 139 - 174). Kyiv : Lybid [in Ukrainian].

12. Lozova V. I. (2002). Tsilisnyi pidkhid do formuvannia piznavalnoi aktyvnosti shkoliariv.[A holistic approach to the formation of cognitive activity of pupils]. Kharkiv : Osnova [in Ukrainian].

13. Rachynskaia, E.Y., Sydorenko V.Y. (2002). Modelyrovanye y khudozhestvennoe oformlenye odezhdy [Modeling and decoration of clothing]. Rostov $\mathrm{n} / \mathrm{D}$.: Fenyks [in Russian].

14. Rozvytok tvorchykh zdibnostei uchniv osnovnoi zahalnoosvitnoi shkoly z konstruiuvannia ta modeliuvannia odiahu na urokakh trudovoho navchannia. [Development of creative abilities of pupils of primary school for designing and modeling of clothes in the lessons of labor training] - Rezhym dostupu: http://otherreferats.allbest.ru/pedagogics/00320680_0.html (data zvernennia: 21.07.2019) - Nazva z ekrana [in Ukrainian].

15. Khutorskoi A. V. (2003). Dydaktycheskaia эvrystyka. Teoryia y tekhnolohyia kreatyvnoho obuchenyia. [Didactic heuristics. Creative learning theory and technology]. Moskva : Yzd-vo MHU [in Russian].

\section{АНОТАЦІЯ}

Процес проєктування нових дизайнерських об'єктів, зокрема в модній індустрії, $\epsilon$ надзвичайно складним і багатоелементним, оскільки в ньому задіяні не тільки розум, знання та вміння мития, але і його внутрішні почуття та спостереження. Цей процес складається з низки визначених етапів - від ідеї-задуму, через постановку задач, формування концепції та вибору поєднаних у різній послідовності прийомів, засобів та методів проєктування до втілення задуму в життя. Питання вибору і застосування одного окремого методу проєктування чи їх комплексу в кожному випадку, що розглядається, постає перед розробником і вимагає від нього як усвідомлення проєктних завдань, так і розуміння можливостей вжитих методів. Для розв'язання творчої задачі застосування традииійних методів проєктування не дає нових цікавих рішень. Тому важлива активізація творчого пошуку, спрямована на розвиток творчих здібностей студента та інтенсифрікацію самого процесу проєктування. Плідним може бути вивчення і практичне впровадження разом з традиційними емпіричними прийомами нетрадииійних методів, так званих технологічних прийомів творчості. Вони можуть бути з успіхом використані в навчанні художнього проєктування одягу в закладах вищої освіті.

Існує безліч найрізноманітніших евристичних методів, здатних пробудити у студентів ініціативу, розкрити їх індивідуальні творчі здібності, розвинути креативність у професійному напрямку, регулювати й інтенсифікувати процес творчого пошуку. Поряд із цим, існуе потреба в опрацюванні методів навчання художнього проєктування одягу студентів та адаптації до сучасних навчальних програм закладів вищої освіти, поширенні досвіду вивчення нових педагогічних технологій. Отже, важливим завданням виділяємо впровадження системи евристичних методів у педагогічну практику.

Ключові слова: евристичні методи, евристичне навчання, методи проєктування одягу, художнє проєктування одягу, творчі здібності. 